\title{
Pembelajaran Self Study Pada Program Paket A Di Pusat Kegiatan Belajar Masyarakat (PKBM) Rantenase Kota Palopo
}

Eidhy Rustan, State Institute for Islamic Studies (IAIN) Palopo, edhy_rustan@iainpalopo.ac.id
Badleria, State Institute for Islamic Studies (IAIN) Palopo, baderia@iainpalopo.ac.id
Rah-mat Tamrin, State Institute for Islamic Studies (IAIN) Palopo, rahmattamrin096@gmil.com

Hhstract: This study aims to determine the Self Study learning form in package A program at the Cum-unity Learning Center (PKBM) Rantenase Palopo City. The subjects of this study were educators and package A students with a total of 40 students in 2017 in PKBM Rantenase. This research is a descriptive qualitative type of research, the research was conducted in Peta Village, Sandana District, Palispo City. Data collection techniques used were observation, interviews, and documentation. Management techniques and data analysis used are: data management and data analysis, the results of the study indicate that the learning increased significantly with the package A Self Study learning model implemented by PKBM Rantenase, which aims to give the local community the disadvantage of education. Therefore, students experience changes both in skill, experience and educational knowledge from the sults of the learning process activities.

Faysords: Self study, Package a program, Community learning activity center 


\section{INTRODUCTION}

Pendidikan merupakan sebuah pembelajaran, pengetahuan, keterampilan, dan kebiasaan seseorang atau sekelompok orang yang diturunkan dari satu generasi ke generasi berikutnya melalui pengajaran, pelatihan, atau penelitian. Program paket A adalah program kesetaraan setingkat SD yang diatur di dalam Undang-Undang Nomor. 20 Tahun 2003 tentang Sistem Pendidikan Nasional, pasal 26, ayat 6 hasil pendidikan nonformal dapat dihargai setara dengan hasil pendidikan formal setelah melalui proses penilaian penyetaraan oleh lembaga yang ditunjuk oleh Pemerintah atau Pemerintah Daerah dengan mengacu pada standar nasional pendidikan (Undang-Undang Sisdiknas 2013:18). Adapun tujuan pendidikan menurut Ridwan Abdullah Sani (2013:15). Tujuan pembelajaran merupakan aktivitas belajar yang direncanakan merupakan perilaku yang diharapkan dapat dicapai dan dimiliki oleh peserta didik.

Pendidikan adalah salah satu kewajiban bagi seluruh umat manusia yang harus dituntut dan ditekuni serta dimiliki. Sebagaimana yang telah dijelaskan didalam al-Qur'an bahwa Allah swt., akan mengangkat derajat orang- orang yang beriman dan berilmu. Sebagaimana yang tercantum dalam (QS. Al-Mujadilah /58:11) Allah swt., menganjurkan kepada manusia agar senantiasa mau bekerja keras, dalam menuntut ilmu maupun bekerja mencari nafkah, hanya orang yang rajin belajar yang akan mendapatkan banyak ilmu, dan hanya orang-orang yang berilmu yang memiliki semangat kerja untuk meraih kebahagiaan hidup.

Pendidikan berfungsi membantu peserta didik dalam pengembangan dirinya, yaitu pengembangan semua potensi, kecakapan, keterampilan, serta karakteristik pribadinya kearah yang positif, baik bagi dirinya maupun lingkungannya (Nana Syaodih Sukmadinata, 2009:4). Sebagai tenaga pengajar, pendidik perlu meningkatkan kinerjanya dan membentuk kecakapan dalam diri pribadi peserta didik dalam mencapai tujuan pendidikan (Rustan \& Bahru, 2018). Pendidikan sering terjadi di bawah bimbingan orang lain, tetapi juga memungkinkan secara mandiri. Mandiri dapat diartikan sebagai belajar secara sendiri untuk akhirnya mampu menguasai keahlian tertentu (M. Firdaus Agung 2017:10). Kegiatan belajar secara mandiri menjadi sangat efektif dan bisa mengembangkan keterampilan yang dimiliki. Karena dalam belajar secara mandiri pembelajar dituntut untuk bertanggung jawab kepada diri pembelajar sendiri. Pembelajar bisa melatih diri dengan cara mampu mengenali kekurangan yang dimiliki dan mencoba mencari cara untuk memperbaiki kekurangan tersebut. Pembelajar akan menjadi manusia yang bebas karena bisa dengan fleksibel mengatur waktu untuk belajar, pembelajar bisa menentukan sendiri kapan meluangkan waktu untuk belajar.

Elaine B. Johnson dalam bukunya Contextual Teaching and Learning meyebutkan bahwa pembelajaran mandiri merupakan pembelajaran yang mengutamakan pengamatan aktif dan mandiri. Pembelajaran mandiri juga melibatkan pengaitan studi akademik dengan kehidupan sehari-hari dalam cara yang bermakna untuk mencapai tujuan yang berarti. Kerja sama, sebagai bagian penting dari contextual teaching learning (CTL) memainkan peran penting dalam pembelajaran mandiri (Elaine B. Johnson 2012:149). Menurut Wedemcyer, perserta didik yang belajar secara mandiri mempunyai kebebasan untuk belajar tanpa harus menghadiri pembelajaran yang diberikan guru/pendidik di kelas (Rusman 2016:353).

Proses pembelajaran merupakan suatu peristiwa yang melibatkan kedua pihak dengan pemikiran yang berbeda, tetapi mempunyai tujuan yang sama yaitu meningkatkan pembelajaran (Syamsu, 2017: 9). Menurut Burton dalam Usman dan Setiawati, belajar dapat diartikan sebagai perubahan tingkah laku pada diri individu berkat adanya interaksi antara individu dengan indivudu lain dan individu dengan lingkungannya sehingga mereka lebih mampu berinteraksi dengan lingkungannya (Ahmad Susanto, 2013:3). Sementara menurut E.R. Hilang, belajar adalah suatu perubahan kegiatan terhadap lingkungan. Perubahan kegiatan yang dimaksud mencakup pengetahuan, kecakapan, tingkah laku, dan ini diperoleh melalui latihan (pengalaman). Belajar tidak hanya dipahami sebagai aktivitas yang dilakukan oleh pelajar saja. Belajar juga merupakan aktivitas yang dilakukan seseorang untuk mendapatkan perubahan dalam dirinya melalui pelatihan-pelatihan atau pengalaman (Baharuddin dan Esa Nurwahyuni 2012:12). Menurut defenisi Kimble belajar berasal dari praktik yang diperkuat dengan kata lain, hanya perilaku yang diperkuat yang akan dipelajari (B.R. Hergenhahn, Matthew H. Olson, 2010:8). Belajar 
manfaat Pembelajaran Self Study Pada Program Paket A di Pusat Kegiatan Belajar Masyarakat (PKBM) Rantenase Kota Palopo.

\section{METHOD}

Jenis penelitian yang digunakan adalah penelitian kualitatif merupakan metode penelitian yang berlandaskan pada filsafat postpositivisme. Sugioni (2009:9). Penelitian ini bertujuan untuk mendeskripsikan informasi tentang status gejala dari objek penelitian dalam bentuk narasi. Penelitian ini dilakukan di Pusat Kegiatan Belajar Masyarakat (PKBM) Rantenase, Keluarahan Peta, Kecamatan Sandana, Kota Palopo. Sumber data pada penelitian ini adalah peserta didik program paket A PKBM Rantenase. Subjek penelitian ini pendidik dan peserta didik dengan jumlah 40 peserta didik.

Adapun teknik pengumpulan data pada penelitian ini adalah observasi, wawancara, dan dokumentasi dengan menggunakan pendekatan pedagogis, yuridis formal, dan teologis normatif. Analisis data pada penelitian ini menggunakan model huberman dan miles, yakni meliputi reduksi data, penyajian data, dan verivikasi/penarikan kesimpulan. Teknik keabsahan data pada penelitian ini menggunakan dua cara yakni: 1) perpanjangan pegamatan dalam hal ini peneliti melakukan kembali ke Pusat Kegiatan Belajar Masyarakat (PKBM) Kota Palopo untuk mengamati dan melakukan wawancara terhadap pendidik dan peeserta didik guna mendapatkan informasi lebih lengkap. 2) meningkatkan ketekunan dimaksudkan peneliti melakukan pengamatan secara lebih cermat dan berkesinambungan agar kepastian data dan urutan peristiwa dapat dipercaya.

\section{RESULTS}

\section{Bentuk Pembelajaran Self Study Pada Program Paket A di Pusat Kegiatan Belajar Masyarakat (PKBM) Rantenase Kota Palopo.}

Pelaksanaan pembelajaran di Pusat Kegiatan Belajar Masyarakat (PKBM) Rantenase Kota Palopo melaksanakan pembelajaran terstruktur meliputi tiga kegiatan pokok diantaranya: pelaksanaan, perencanaan, dan evaluasi. Proses pelaksanaan pembelajaran Self Studi pada program paket A di Pusat Kegiatan Belajar Masyarakat (PKBM) Rantenase Kota Palopo. Pada umumnya sangat berbeda dengan pembelajaran yang ada di sekolah formal yakni Sekolah Dasar, proses pelaksanaan pembelajaran yang di laksanakan di PKBM Rantenase hanya tiga kali $(3 \mathrm{x})$ dalam seminggu ini di kerenakan lokasi pembelajaran yang sangat jauh dari masyarakat setempat khususnya di Kelurahan Peta Kecamatan Sendana, sehingga bagaimana peserta didik diberikan kemandirian pada diri peserta didik maka pendidik yang ada di PKBM Rantenase memberikan buku paket panduan kepada peserta didik untuk dia pelajari pada saat pembelajaran berlangsung, bukan pada saat pembelajaran di mulai akan tetapi peserta didik lebih bayak waktu belajar yang di berikan pada saat di rumah atau tempat tinggal dia masingmasing, disamping itu juga peserta didik di berikan tugas individu untuk dia kerjakan pada saat berada di tempat tinggal masing-masing sehingga mempunyai tanggung jawab pada diri peserta didik serta inisiatif yang tinggi yang dimiliki peserta didik untuk terus belajar (Budi Jamin, 24 Mei 2018).

Senada dengan hasil wawancara bapak Budi Jamin, menurut Jupri Pamin wawancara (05 juni 2018).

"mengemukakan bahwa proses pelaksanaan pembelajaran yang dilaksanakan di PKBM Rantenase jelas sangat berbeda yang dilaksanakan di sekolah dasar atau di sekolah formal tingkat dasar, yang dimana proses pelakanaan pembelajarannya hanya tiga kali $(3 \mathrm{x})$ petemuan dalam seminggu selama satu tahun. Ini dikarenakan lokasi pembelajaran yang sangat jauh dari pusat kota dan untuk menempuh lokasi pembelajaran, pendidik atau tutor melalui pegunungan-pegunungan yang berada di Kelurahan Peta, Kecamatan Sendana." 
Berdasarkan beberapa hasil wawancara diatas dengan peserta didik, maka penulis dapat mengambil satu kesimpulan bahwa betapa pentingnya suatu pendidikan bagi masyarakat khususnya Kelurahan Peta yang tertinggal akan pendidikan. Olehnya pembelajaran Self Study pada program paket A sangat memberikan manfaat kepada peserta didik itu sendiri baik dari aspek pengetahuan maupun keterampilan

\section{DISCUSSION and CONCLUSION}

Berdasarkan hasil penelitian terhadap pembelajaran Self Study pada program paket A di Pusat Kegiatan Belajar Mayarakat (PKBM) Rantenase Kota Palopo. Diketahui bahwa peserta didik telah memiliki banyak perubahan-perubahan baik dari segi aspek afektif, kognitif, dan psikomotorik melalui model pembelajaran Self Study. Self Study dimaknai melakukan investigasi untuk menambah wawasan baru (Dinkelman, 2003). Pembelajaran self study merupakan kegiatan pembelajaran dari pengalaman sendiri yang kemudian di evaluasi untuk mendapatkan pengalaman baru (Craig, 2008). Agar lebih efektif pembelajaran self study dilakukan secara berkelompok (Vanassche \& Kelchtermans, 2015). Akibatnya adalah dapat memberikan pengaruh positif bagi perkembangan peserta didik baik dari segi pengetahuan dan keterampilan. Menurut Winkel belajar merupakan aktivitas mental/psikis yang berlangsung dalam interaksi aktif dengan lingkungan yang menghasilkan perubahan-perubahan dalam pengetahuan, keterampilan dan sikap (Purwanto, 2014:39). Sedangkan pendidikan didefenisikan sebagai proses rekonstruksi pengalaman yang menambah makna pengalaman dan meningkatkan kemampuan untuk mengarahkan ke pengalaman selanjutnya (Dinkelman, 2003). Teori tersebut sejalan dengan hasil penelitian serta observasi dilapangan menunjukkan bahwa dalam pembelajaran program paket A di PKBM Rantenase. Peseta didik mendapatkan pengalaman-pengalaman, serta keterampilan baik dalam pembelajaran In door maupun pembelajaran Out door yang berinteraksi langsung dengan lingkungan alam.

Setelah mengikuti pembelajaran Self Study pada program paket A peserta didik didik tersebut telah mendapatkan ilmu pengetahuan dan keterampilan-keterampilan lainnya. Self study adalah tentang belajar dari pengalaman yang tertanam didalamnya dimana guru menciptakan pengalaman baru untuk mereka sendiri melalui teori yang ada dan pengalaman pribadi yang memberikan wawasan kepada siswa (Laboskey, 2004). Hal ini menunjukkan Pusat Kegiatan Belajar Masyarakat (PKBM) Rantenase sangat memberikan manfaat kepada peserta didik program paket A. Sebagaimana yang telah dijelaskan dalam salah satu hadist ialah:

Dari Habib bin Ubaid ia berkata: "Pelajarilah ilmu dan ambillah manfaat, dan janganlah kalian mempelajarinya karena ingin memperbagus diri dengan ilmu. Siapa tahu kalian berumur panjang, dan ketika itu orang yang mempunyai ilmu memperbagus dirinya dengan ilmunya seperti orang yang mempunyai kain dan dipergunakannya untuk memperindah diri".

Menurut teori naturalisme romantik dari Jean Jacques Rousseau (Rusman, 2014:386) memandang bahwa individu memiliki potensi-potensi atau kemampuan-kemampuan yang masih terpendam dan memiliki kekuatan sendiri untuk mengembangkan dirinya secara mandiri. Menurut teori Wedemeyer bahwa kemandirian dalam belajar perlu diberikan kepada peserta didik supaya mereka mempunyai tanggung jawab dalam mengatur dan mendisiplinkan dirinya dan dalam mengembangkan kemampuan belajar atas kemauan sendiri (Rusman, 2014:354). Pembelajaran Self Study menjadikan pelajar lebih leluasa untuk mengeksplor kemampuannya dan mampu menjadi tolak ukur psikologis peserta didik terkait kepribadian, proses pengembangan diri, praktik pengungkapan diri serta introspeksi diri (J. J. Loughran, 2004). Teori tersebut sejalan dengan hasil penelitian menunjukkan bahwa pembelajaran Self Study program paket A di PKBM Rantenase peserta didik diberikan buku panduan berupa modul sebagai pedoman pembelajaran berlangsung serta tugas pekerjaan rumah untuk mereka kerjakan agar peserta didik memiliki tanggung jawab untuk menyelesaikan tugas tersebut. 
Adapun aspek penting dalam pembelajaran self study adalah proses produksi pengetahuan yang dikemas dalam bentuk praktik pengetahuan sehingga pelaksanaan pembelajaran self study membutuhkan keseimbangan antara pelaksanaan dan pembelajaran (J. Loughran, 2010; Pithouse, Mitchell, \& Weber, 2009). Dalam praktik pembelajaran self study guru berperan sebagai mediator antara materi pelajaran dan peserta didik. Guru mendorong siswa untuk bertanggung jawab atas perkembangan diri mereka sendiri melalui kolaborasi, komunikasi dan refleksi. Namun agar siswa termotivasi mengikuti proses pembelajaran, guru perlu meyakinkan siswa akan kemamuan yang dimiliki karena self efficacy berpengaruh terhadap motivasi, afektif dan pemilihan kegiatan (Thaha \& Rustan, 2017). Atau secara sederhana peserta didik menganggap dirinya tidak mampu dan tidak efisien belajar mandiri karena self efficacy didefenisikan sebagai keyakinan sejauh mana peserta didik mampu belajar mandiri. Rendahnya self efficacy menyebabkan stres akibat tekanan proses pembelajaran (Evers, And, \& Tomic, 2002).

Adapun dari hasil analisis data penelitian skripsi dengan judul "Pembelajaran Self Study Pada Program Paket A Di Pusat Kegiatan Belajar Masyarakat (PKBM) Rantenase Kota Palopo", maka dapat diambil kesimpulan sebagai berikut: 1) Pusat Kegiatan Belajar Masyarakat (PKBM) Rantenase Kota Palopo merupakan sebuah lembaga pendidikan non formal yang sejatinya memberdayakan masyarakat dengan menggunakan model pembelajaran Self Study khususnya di kelurahan peta dengan melalui program paket A yang setara dengan sekolah dasar (SD). Hal tersebut dapat dilihat bahwa hasil pembelajaran yang terjadi sesuai dengan harapan pendidik. 2) Dalam upaya pelaksanaan pembelajaran yang lebih efektif dan efesien, maka pendidik di PKBM Rantenase telah melakukan pembelajaran Self Study, baik dilaksanakan dengan pembelajaran In Door (didalam ruangan) dan pembelajaran Out Door (diluar ruangan) serta pembelajaran Life Skill. 3) Pendidik dalam menunjang keberhasilan belajar peserta didik dalam pembelajaran Self Studi di PKBM Rantenase didukung oleh semangat, motivasi, serta krearivitas pendidik dalam proses belajar mengajar.

\section{REFERENCES}

Aqib Zainal. 2010, Profesional Guru dalam Pembelajaran. Surabaya: Insan Cendikia.

Abdullah Sani Ridwan, 2013. Inovasi Pembelajaran, Cet. I; Jakarta, Bumi Aksara.

Baharuddin dan Esa Nur wahyuni. 2015, Teori Belajar dan Pembelajaran, Cet. V; Jogjakarta: Ar-Ruzz Media Widya.

B.R. Hergenhahn, dan Matthew H. Olson, 2010. Theories Of Learning, Cet. III, Jakarta, Kharisma Putra Utama, Kencana.

Sunan Ad Darimi/ Abu Muhammad Abdullah bin Abdurrahman bin Bahram Addarimi, (Kitab Mukaddimah, Darul Kutub Ilmiyah/ Bairut-Libanon, Juz 1).

Uno B Hamzah. 2015, Teori Motivasi dan Pengukurannya. Cet. 12. Jakarta: Bumi Aksara.

Purwanto. 2014, Evaluasi Hasil Belajar, Cet. VI, Yogyakarta, Pustaka Belajar.

Budiningsih C. Asri. 2005Belajar dan Pembelajaran, Cet. I, Jakarta, Rineka Cipta.

Departemen Agama Republik Indonesia, 2011. Al-Qur'an dan Terjemahannya, (Depok, Cahaya Qur'an)

Firdaus Agung laman diakses tanggal 10 april 2017, Manfaat Belajar Mandiri, http://www.kompasiana com. /mfirdaus agung/manfaat belajar secara mandiri

Johnson Elaine B. 2010, Contextual Teaching and Learning, Cet. IV, Bandung, Kaifa Learning.

Kementerian Pendidikan dan Kebudayaan. 2012, Standar dan Prosedur Penyelenggaraan Pusat Kegiatan Belajar Masyarakat (PKBM), (Cet.I; Jakarta: Direktorat Pembinaan Pendidikan Masyarakat Direktorat Jenderal Pendidikan Anak Usia Dini Nonformal dan Informal).

Majid Abdul, 2012. Belajar dan Pembelajaran Pendidikan Agama Islam, Cet. I, Jakarta, Rosdakarya Offset. 